\title{
Antibiotic prophylaxis, dental treatment and arthroplasty: time to explode a myth
}

Prosthetic joint replacement is a major achievement of orthopaedic surgery. There has been much research on surgical technique, survival rates of prostheses ${ }^{2}$ and the use of thromboprophylaxis, ${ }^{3}$ but one issue has apparently escaped scientific rigour in favour of personal beliefs, namely the need for prophylaxis against infection in patients with replacements who are to have dental treatment.

In 1985 a survey of orthopaedic surgeons in the USA showed that over $90 \%$ recommended prophylactic antibiotics before the dental treatment of patients with arthroplasties. $^{4}$ Thyne and Ferguson in $1991^{5}$ found no convincing evidence to support this policy, but suggested that antibiotics may be justified for patients with rheumatoid arthritis, reoperated hips, diabetes and those on steroids since they "constitute a group at higher risk". In 1992 a working party for the British Society for Antimicrobial Chemotherapy (BSAC) reported that prophylactic antibiotics were not required, ${ }^{6}$ but made no specific mention of any higher-risk groups.

We recently reported a postal survey of 250 orthopaedic surgeons in the $\mathrm{UK}^{7}$ in which they were asked about their recommendations for patients with primary arthroplasties, revisions or rheumatoid arthritis and those on steroids or other immunosuppressive therapy. They were also asked which antibiotic they recommended. Of the 113 respondents, $77.7 \%$ always recommended antibiotics for patients with prosthetic hips who required dental treatment. More surgeons gave such advice for those with revised arthroplasties or rheumatoid arthritis $(81 \%)$ and those on longterm steroids $(87 \%)$ or immunosuppressive therapy $(91.3 \%)$. The antibiotic most recommended was a cephalosporin (49\%).

The incidence of late infection in arthroplasties has been quoted as from $<0.1 \%{ }^{8}$ to $0.6 \%{ }^{9}$ with organisms from a dental source involved in from $0.04 \%{ }^{10}$ to $0.07 \%$. $^{9}$ Even these very small proportions may derive from bacterio-

\footnotetext{
S. S. Sandhu, FDSRCS, Honorary Registrar

J. C. Lowry, FDSRCS, FRCS, Consultant Oral and Maxillofacial Surgeon

M. E. Morton, FDSRCS, Consultant Oral and Maxillofacial Surgeon Department of Oral and Maxillofacial Surgery, Blackburn Royal Infirmary, Bolton Road, Blackburn BB2 3LR, UK.

S. F. Reuben, FRCS, Specialist Registrar in Orthopaedic Surgery Furness General Hospital, Dalton Lane, Barrow-in-Furness, Cumbria LA14 4LF, UK.

Correspondence should be sent to Mr S. S. Sandhu at 21 Arley Avenue, West Didsbury, Manchester M20 2LQ, UK.

(C)1997 British Editorial Society of Bone and Joint Surgery 0301-620X/97/47867\$2.00

J Bone Joint Surg [Br] 1997;79-B:521-2.
}

logical methods which may be flawed: ${ }^{11}$ the actual incidence of joint infection secondary to dental treatment is perhaps even lower. Transient bacteraemia of oral organisms may occur spontaneously, without major dental treatment. Roberts et $\mathrm{al}^{12}$ have shown that simple tooth-brushing produced a detectable bacteraemia in $38.5 \%$ of 52 children, and in older patients with periodontal disease the proportion is probably even higher. Such episodes of spontaneous bacteraemia may occur up to 12 times each day, that is over 4000 per year (Roberts, personal communication), and it would seem illogical to advise antibiotic cover for the few episodes caused by a dental surgeon.

Most orthopaedic surgeons chose a cephalosporin for prophylaxis before dental treatment despite the evidence that this is ineffective against the haematogenous seeding of the most common oral organism, Streptococcus viridans. $^{13}$ Orthopaedic surgeons seem to recommend the antibiotic regimes which are used routinely at the time of primary surgery and do not take into account the different organisms which occur in the month. In a wider context, unnecessary use of antibiotics is known to be a cause of increasing bacterial resistance in both hospitals ${ }^{14,15}$ and the community. ${ }^{16}$ This increasing problem requires critical analysis of the prescribing habits of all practitioners.

It seems that few orthopaedic surgeons have policies that are based on existing scientific knowledge. Patients are given antibiotics which are not effective to prevent episodes of bacteraemia which are very common and rarely have any harmful effect. Understandable concern about the disaster of an infected arthroplasty has led to management which is not practical and, more importantly, not in the best interests of the patient. There is no scientific evidence to support the view that patients with arthroplasties, even in the high-risk groups, require antibiotic prophylaxis during dental treatment.

The ever-increasing number of such patients is best served by the adoption of the following measures:

1) All should visit their dental practitioner before their arthroplasty for the elimination of gross dental disease, and advice on oral hygiene.

2) All should subsequently have regular dental check-ups.

3) Prophylactic antibiotics should not be given by dental surgeons before treatment.

4) Patients with orofacial infection should have prompt antibiotic therapy using drugs known to be active against the organisms which commonly cause such infections.

S. S. SANDHU J. C. LOWRY M. E. MORTON S. F. REUBEN 


\section{REFERENCES}

1. Phillips AM, Goddard NJ, Tomlinson JE. Current techniques in total knee replacement: results of a national survey. Ann R Coll Surg Engl 1996;78:515-20.

2. Neumann L, Freund KG, Sørenson KH. Long-term results of Charnley total hip replacement: review of 92 patients at 15 to 20 years. J Bone Joint Surg [Br] 1994;76-B:245-51.

3. Unwin AJ, Jones JR, Harries WJ. Current UK opinion on thromboprophylaxis in orthopaedic surgery: its use in routine total hip and knee arthroplasty. Ann R Coll Surg Engl 1995;77:351-4.

4. Jaspers MT, Little JW. Prophylactic antibiotic coverage in patients with total arthroplasty: current practice. J Am Dent Ass 1985;111: 943-8.

5. Thyne GM, Ferguson JW. Antibiotic prophylaxis during dental treatment in patients with prosthetic joints. J Bone Joint Surg [Br] 1991;73-B:191-4.

6. Simmons NA, Ball AP, Cawson RA, et al. Case against antibiotic prophylaxis for dental treatment of patients with joint prostheses. Lancet 1992;339:301.

7. Sandhu SS, Lowry JC, Reuben SF, Morton ME. Who decides on the need for antibiotic prophylaxis in patients with major arthroplasties requiring dental treatment: is it a joint responsibility? Ann $R$ Coll Surg Engl 1997;79:143-7.
8. Lidwell OM, Elson RA, Lowbury EJL, et al. Ultraclean air and antibiotics for prevention of postoperative infection. Acta Orthop Scand 1987;58:4-13.

9. Maderazo EG, Judson S, Pasternak H. Late infections of total joint prostheses: a review and recommendations for prevention. Clin Orthop 1988;229:131-42.

10. Little JW. The need for antibiotic coverage for dental treatment of patients with joint replacements. Oral Surg Oral Med Oral Pathol 1983;55:20-3.

11. Field EA, Martin MV. Prophylactic antibiotics for patients with artificial joints undergoing oral and dental surgery: necessary or not? Br J Oral Maxillofac Surg 1991;29:341-6.

12. Roberts GJ, Holzel HS, Sury MRJ, et al. Dental bacteremia in children. Pediatr Cardiol 1997;18:24-7.

13. Durack DT, Petersdorf RG. Chemotherapy of experimental streptococcal endocarditis. I. Comparison of commonly recommended prophylactic regimens. J Clin Invest 1973;52:592-8.

14. McGowan JE Jr. Antimicrobial resistance in hospital organisms and its relation to antibiotic use. Rev Infect Dis 1983;5:1033-48.

15. Neu HC. The crisis in antibiotic resistance. Science 1992;257: 1064-73.

16. Arason VA, Kristinsson KG, Sigurdsson JA, et al. Do antimicrobials increase the carriage rate of penicillin resistance pneumococci in children? Cross sectional prevalence study. BMJ 1996;313:387-91. 